\title{
Activation of heme-free soluble guanylate cyclase with cinaciguat has beneficial cardiorenal actions when added to furosemide in experimental heart failure
}

\author{
Guido Boerrigter $^{1 *}$, Lisa C Costello-Boerrigter ${ }^{1}$, Alessandro Cataliotti ${ }^{1}$, Johannes-Peter Stasch², John C Burnett Jr. ${ }^{1}$ \\ From 5th International Conference on cGMP: Generators, Effectors and Therapeutic Implications \\ Halle, Germany. 24-26 June 2011
}

\section{Background}

Volume overload and sodium retention in congestive heart failure (HF) are usually treated with loop diuretics. However, worsening renal function is frequently observed and is associated with worse outcomes. Soluble guanylyl cyclase (sGC) plays an important role in renal function. Importantly, sGC activation can be impaired in cardiorenal disease states, which can be due to not only decreased bioavailability of nitric oxide but also to heme oxidation or heme loss of sGC, which renders the enzyme insensitive to NO. Cinaciguat is a novel sGC activator that stimulates the heme-free, NO-insensitive form of sGC.

\section{Hypothesis}

Cinaciguat unloads the heart and increases renal blood flow without compromising renal function when added to furosemide in experimental HF.

\section{Methods}

HF was induced in canines $(n=13)$ by tachypacing. On day 11 of pacing, an acute study was performed under general anesthesia. The left ureter was catheterized and the renal artery was equipped with a flow probe. After equilibration a 30 -minute baseline clearance $(\mathrm{C} 1)$ was done. After this, animals were assigned to one of two groups. One group received furosemide $(1 \mathrm{mg} / \mathrm{kg} / \mathrm{h})$ for 90 minutes, the other group received the same dose of furosemide plus cinaciguat ( 0.1 followed by $0.3 \mu \mathrm{g} / \mathrm{kg} /$ min for 45 minutes each). Two clearances (C2 and C3)

\footnotetext{
* Correspondence: Boerrigter.quido@mayo.edu

${ }^{1}$ Cardiorenal Research Laboratory, Mayo Clinic, Rochester, MN, USA

Full list of author information is available at the end of the article
}

were done from 15-45 and from 60-90 minutes of drug infusion. After a 30-minute washout a post-infusion clearance $(\mathrm{C} 4)$ was done. ${ }^{*} \mathrm{p}<0.05$ between groups.

\section{Results}

In the furosemide group, mean arterial pressure was not changed during drug administration but decreased during C4. Cardiac output and systemic and pulmonary vascular resistances were unchanged. Right atrial, pulmonary artery, and pulmonary capillary wedge pressures were reduced during $\mathrm{C} 3$ and $\mathrm{C} 4$. In the furosemide + cinaciguat group, mean arterial pressure* and systemic* and pulmonary* vascular resistances decreased in $\mathrm{C}^{*}$, $\mathrm{C}^{*}$, and $\mathrm{C}^{*}$. The same was true for right atrial*, pulmonary artery* and pulmonary capillary wedge pressures*. Cardiac output increased in $\mathrm{C} 2^{*}, \mathrm{C} 3^{*}$, and $\mathrm{C} 4^{*}$. Furosemide alone did not change renal blood flow, whereas furosemide+cinaciguat increased it in $\mathrm{C} 2, \mathrm{C} 3^{*}$, and $\mathrm{C} 4$. Urine flow and urinary sodium excretion increased in both groups during $\mathrm{C} 3$ and $\mathrm{C} 4$ with no differences between groups. Glomerular filtration rate increased with furosemide alone during drug infusion, while this tended to be the case in the furosemide+cinaciguat group, with no differences between groups $(\mathrm{p}>0.4)$.

\section{Conclusion}

Cinaciguat when added to furosemide reduces cardiac preload and afterload and increases renal blood flow when compared to furosemide alone. Importantly, GFR and sodium excretion were not negatively affected by cinaciguat, despite the reduction in mean arterial pressure. It remains to be established whether these 
promising findings can translate into improved renal outcomes in patients with HF.

\section{Author details}

${ }^{1}$ Cardiorenal Research Laboratory, Mayo Clinic, Rochester, MN, USA.

${ }^{2}$ Cardiovascular Research, Bayer Schering Pharma AG, Wuppertal, Germany.

Published: 1 August 2011

doi:10.1186/1471-2210-11-S1-P10

Cite this article as: Boerrigter et al:: Activation of heme-free soluble guanylate cyclase with cinaciguat has beneficial cardiorenal actions when added to furosemide in experimental heart failure. $B M C$ Pharmacology 2011 11(Suppl 1):P10.

Submit your next manuscript to BioMed Central and take full advantage of:

- Convenient online submission

- Thorough peer review

- No space constraints or color figure charges

- Immediate publication on acceptance

- Inclusion in PubMed, CAS, Scopus and Google Scholar

- Research which is freely available for redistribution

Submit your manuscript at www.biomedcentral.com/submit 